\title{
Observations on the diving behaviour and defensive strategies of the endemic, semi-aquatic lizard Potamites erythrocularis (Squamata: Gymnophtalmidae)
}

\author{
CRISTINA ARRIVILLAGA ${ }^{1, *} \&$ BERIT QUINKERT ${ }^{1}$ \\ ${ }^{1}$ Crees Foundation. Fundo Mascoitania, Manu, Madre de Dios, Peru \\ *Corresponding author e-mail: cristinaarrivillaga@gmail.com
}

$\mathrm{L}$ izards of the genus Potamites (Doan \& Castoe, 2005) are -semi-aquatic and are known to inhabit riparian habitats and may even be found beneath rocks in streams (ChávezArrisbaplata et al., 2015). We have found no information describing their adaptations to a semi-aquatic lifestyle, such as their diving behaviour or apnea abilities, but were fortunate to observe these for Potamites erythrocularis, a recently described species from the highlands of Manu National Park in south-east Peru (Chavez \& Catenazzi, 2014).

On the 14 of April 2019 at $12.52 \mathrm{~h}$, we observed a male $P$. erythrocularis (Fig. 1) $(\mathrm{SVL}=7 \mathrm{~cm}$, tail length $=7.1 \mathrm{~cm}$, weight 9 g) submerged in a stream $\left(12.802573^{\circ} \mathrm{S}, 71.403664^{\circ} \mathrm{W}\right.$, WGS 84, $525 \mathrm{~m}$ elev.) in the regenerated forest reserve of the Manu Learning Centre (MLC), a research station situated in the buffer zone of the Manu National Park in south-east Peru. The lizard was submerged $5 \mathrm{~cm}$ underwater with its eyes closed, remaining motionless while positioned between two rocks. After being submerged for ca. 40 seconds, it resurfaced to breathe for approximately 1 to 2 seconds, with only its nostrils breaking the surface of the water. This behaviour was repeated for a total of 10 minutes, remaining underwater for up to 1.5 minutes and only resurfacing for a few seconds to breathe in the manner already described. Following this observation, we decided to catch the lizard to collect morphological data. Upon capture, the lizard began thrashing its body and bit the first authors' hand. Shortly after, it started performing a spinning manoeuver that made it extremely hard to hold. This movement was similar to the "death roll" behaviour exhibited by crocodilians when subduing prey (Fish et al., 2007). Upon further inspection, we observed evidence of tail regrowth (Fig. 2). The individual also produced a cloacal discharge.

Diving has been reported in several families of lizards including the Gymnophtalmidae, with Vitt et al. (1998) documenting this behaviour in another species of Potamites (previously known as Neusticurus). It has been suggested that several aspects of reptile physiology, such as lower metabolic rates and larger lung volume compared to mammals, provide lizards with advantages and adaptations to survive in an aquatic habitat if needed (Heatwole, 1977). The ability to submerge underwater for extended periods of time improves the chances of the lizards catching aquatic prey and of evading terrestrial and diurnal predators (Hare \& Miller, 2009).

Martins (1996) states that semi-aquatic lizards face strong

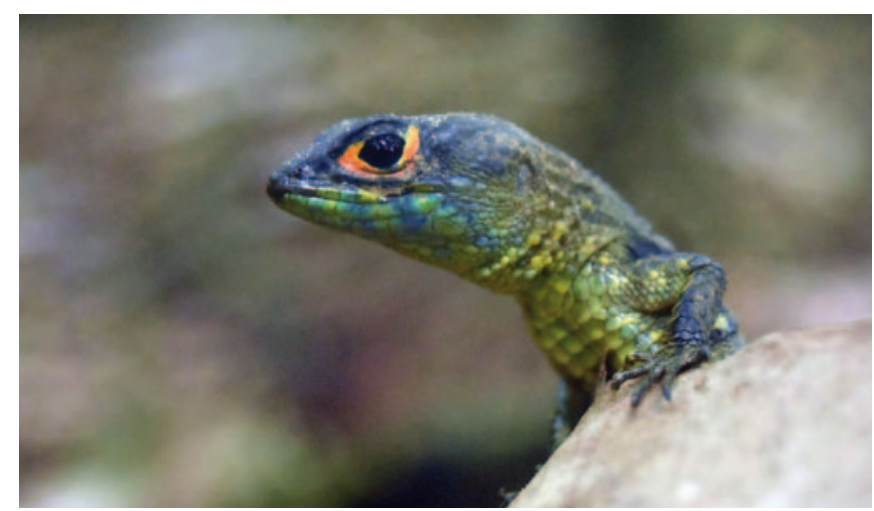

Figure 1. An adult $P$. erythrocularis, a semi aquatic species of Gymnophtalmidae that is endemic to the south-east region of Peru

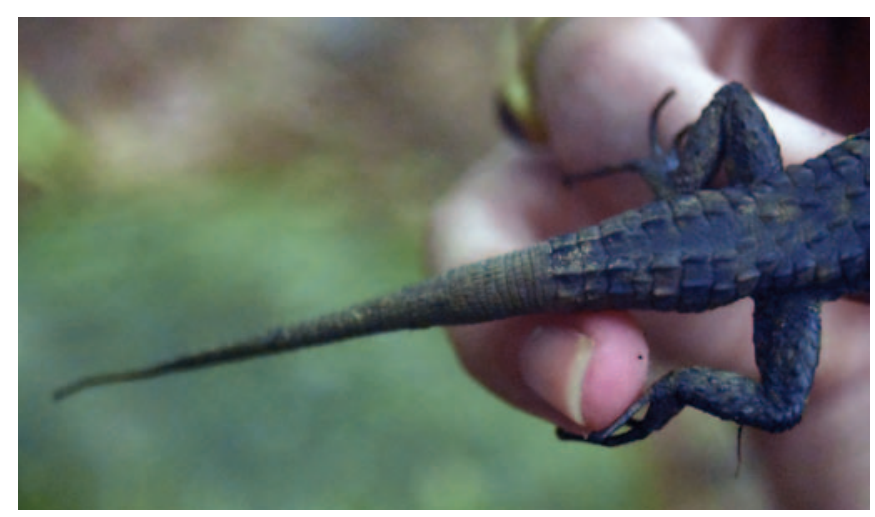

Figure 2. Tail autotomy and regeneration in P. erythrocularis

predation pressure from carnivorous fish and will therefore develop defensive tactics to avoid being preyed upon by both aquatic and terrestrial predators. This would potentially explain the wide array of defensive strategies we observed in P. erythrocularis, which include body rotation, body thrashing, tail autotomy, biting, and cloacal discharge. Rotating the body has been reported in crocodilians for dismembering prey (Fish et al., 2007), and in several species of Amazonian snakes as a defensive mechanism (Martins, 1994), yet it is not commonly documented amongst lizards. At the moment when the individual started to display this behaviour, it made it extremely difficult for the first author to hold on to it, which could prove to be useful while trying to escape a predator's 
grip. Snakes and lizards are also known to use random and unpredictable movements to confuse their potential predators in the form of body thrashing (Martins, 1996).

\section{ACKNOWLEDGMENTS}

We thank the Crees Foundation for providing the opportunity to study the biodiversity in the area and allow us to conduct herpetological research. We would also like to acknowledge Andrew Lee for helping us review this note.

\section{REFERENCES}

Chávez, G. \& A. Catenazzi. (2014). A new Andean lizard of the genus Potamites (Sauria, Gymophthalmidae) from Manu National Park, southeastern Peru. Zootaxa 3774: 45-56.

Doan, T. \& T. Castoe. (2005). Phylogenetic taxonomy of the Cercosaurini (Squamata, Gymophthalmidae), with a new genera for species of Neusticurus and Proctoporus. Zoological Journal of the Linnean Society 143: 405-416.

Fish, F. E., Bostic, S. A., Nicastro, A. J. \& J. T. Beneski. (2007). Death roll of the alligator: mechanics of twist feeding in water. The Journal of Experimental Biology 2010: 28112818.
Greene, H. W. (1988). Antipredator mechanisms in reptiles. In Biology of the Reptilia. Ecology B, Defense and Life History (Gans, C. \& Huey, R. B., eds.). 16: 1- 152.

Hare, K. M. \& K. A. Miller. (2009). What Dives Beneath: Diving as a Measure of Performance in Lizards. Herpetologica 65: 227-236.

Heatwole, H. (1977). Sea snakes, a contrast to other vertebrate divers. Journal of the South Pacific Underwater Medicine Society 7: 35-38.

Martins, M. (1994). História Natural e Ecologia de uma Taxocenose de Serpentes em Mata Primária na Região de Manaus, Amazônia Central, Brasil. PhD dissertation. Universidade Estadual de Campinas, Campinas. 1-98.

Martins, M. (1996). Defensive tactics in lizards and snakes: the potential contribution of the Neotropical fauna. Anais de Etología 14: 185-199.

Vitt, L., Zani, P. A., Avila-Pires, C. S. \& Espósito, M. C. (1998). Geographical Ecology of the gymnophtalmid lizard Neusticurus ecpleopus in the Amazon rainforest. Canadian Journal of Zoology 76: 1671-1680.

Accepted: 27 May 2019 